\title{
Innovative and motivational competence of leaders and its transformation in the context of digitalization
}

\author{
E. Alekhina,V. Parakhina, O. Boris \\ North Caucasus Federal University \\ Russia
}

Received: July 5, 2020. Revised: September 3, 2020. Accepted: September 10, 2020.

Published: September 22, 2020.

\begin{abstract}
The main factor that affected changing competencies in modern conditions is digitalization; the necessity of the interconnected development of innovative and motivational competence of managers is substantiated. The goal of this article is to highlight the most important characteristics of the innovative and motivational competence of organizational leaders. To analyze the competence factors, hypotheses about their change were made, which were tested using two methods: a sociological survey to assess the competencies priority and pairwise comparisons of competency characteristics in terms of their impact on the innovative activity of organizations. The competency model of a modern, innovatively active leader was formed, which included: psychological readiness for change and constant selfdevelopment, a desire to lead the organization to success, the need to be a leader based on innovative style of behavior, knowledge of advanced achievements in the organization's field of activity, experience in introducing inventions, skills to attract investment, understanding the risks of improvement. Our assumptions about the transformation of the leaders' competencies are confirmed. However, estimates of the competencies shift towards motivational components were less significant than expected. Nevertheless, in the context of digitalization, it is very important for innovative leaders to constantly improve their motivational competencies in order to stimulate there highly professional creative workers who create and implement innovations.
\end{abstract}

Keywords - professional competencies, innovative competencies, motivational competences, leader, priority characteristics, competency profile, digitalization.

\section{INTRODUCTION}

Tnnovations, especially digital ones, have now become critically necessary for countries, organizations and individuals as the most important condition for their life and successful activity. Many researchers argue that innovation has become the main driver of economic growth [1]- [3]. A McKinsey questionnaire study confirm sit: more than 70 percent of top managers call innovation "one of the three main drivers of theircompanies' growth in the nextthree to five years" [4].

Management research in recentyears shifts its focus to such a soft variable of the head'swork as competence, which is considered quite widely in various aspects [1], [5], [6].

The innovative activity of the enterprise simplies the presence of a leader with a certain set of innovative and motivational characteristics in their composition. The competence of modern leaders ensures the innovative activity growth of small and large organizations, which, in turn, is the basis of organizational economic growth [2], [6], [7].

The leaders of innovation-oriented companies must be competent in the field of innovation, other wise they will not be able to implement them [8]. That wase videnced by the researches of McKinsey J. Barsh, M. Capozzi, J. Davidson, which revealed "a large gap between the desire of managers to innovate and their ability to perform".Also, most managers do not appreciate their competencies in the field of motivation innovation [4].

The competence concept of innovation leaders is disclosed in the publications of such researchers as Yu. P. Morozov, O.S. Sovetova, M.S. Gençer, \& Y. Samur et al. [9]-[11].

Most researchers [4], [12], [13], [14] define innovative characteristics as a set of certain professionalcompetencies.

Motivational competencies are socio-psychological in nature: the need to be a leader on the innovation basis; the desire to make an organization leading in itsindustry / region; innovative style of behavior; psychological readiness for change and constant self-development, and others [6], [10], [13]. 
According to AwieVlok, competencies for leadership in innovation may differ from those that were used to create and achieve business goals [7]. Also, the economy digitalization affects the qualities required for a successful innovative leader.

\section{MATERIALS AND METHODS}

At the beginning of the study, we formed the competency profile of the leader of an innovative organization. This profile includes competencies identified by innovation leaders. The study began with a list of innovative and motivational competencies from several sources and was based on the research results of McKinsey group, as well as A. Vlok, D. Horth, C.H. Matthews \& R. Brueggemann and others [4], [7], [12], [15].

An analysis of the motivational competencies list allows us to identify external and internal stimulation of innovative activity[16]. In the process of researching the competencies of innovative leaders, the diversity of their competence structure was taken into account.

McKinsey researchers (Joanna Barsh - director of the New York office, Marla Kapozzi - associate director in the Boston office, Jonathan Davidson - director of the London office) also consider an important leadership skill to create a corporate culture of innovation, for which managers themselves must change, acquire new skills in the organization and motivation of staff [4].

McKinsey Group have noted that 94 percent of leaders consider corporate culture to be the most important internal driver of innovation. However, at the same time, most managers do not encourage or model the innovative behavior in employees [4]. In other words, the motivational component of the leaders'competence is not sufficient in the organizations studied in our research.

However, in our opinion, currently there is an increase of motivational competency because digital ones are becoming universal, while knowledge and experience turn out to be outdated very quickly. This hypothesis was put forward by the authors and verified during the study using two methods: a sociological survey to assess the priority of innovative leaders'competencies; application of the pairwise comparisons method of competency characteristics in terms of their impact on the innovative activity of organizations.

In order to identify the priority of the characteristic, five answers are given, each of which corresponds to a numerical value in points. Each answer option calculates the priority of the leader's competencies in points.

\section{RESULTS AND DISCUSSION}

The set of innovative and motivational competencies of the leader was analyzed and presented in the form of the following list of requirements (column 1 of table 1 ).

The matrix of pairwise comparisons was filled in by three groups of respondents: researcher (number 1 in table 1); leader of an innovative organization (number 2 in table 1); small business manager (number 3 in table 1).The result of pairwise comparisons by the three groups of participants in the innovation process in a large organization was performed under the guidance of the authors and presented below in table 1 .

Table 1.The result of pairwise comparisons of motivational and innovative (business) characteristics of leader competencies (developed by the authors based on the study).

\begin{tabular}{|l|c|c|c|c|}
\hline \multirow{2}{*}{ Characteristic } & \multicolumn{3}{|c|}{ Respondents } & \multirow{2}{*}{$\begin{array}{c}\text { Averagegrade } \\
\text { point }\end{array}$} \\
\cline { 2 - 4 } & 1 & 2 & 3 & 10,7 \\
\hline $\begin{array}{l}\text { 1. Psychological readiness for change } \\
\text { and constant self-development }\end{array}$ & 10 & 7 & 15 & 13,3 \\
\hline $\begin{array}{l}\text { 2. The desire to lead the organization } \\
\text { to success }\end{array}$ & 15 & 12 & 13 & \\
\hline $\begin{array}{l}\text { 3. The need to be a leader based on } \\
\text { innovation }\end{array}$ & 9 & 3 & 9 & 7,0 \\
\hline 4. An innovative style of behavior & 4 & 2 & 1 & 2,3 \\
\hline $\begin{array}{l}\text { Sum of grades on motivational } \\
\text { characteristics }\end{array}$ & 38 & 23 & 38 & 33,0 \\
\hline $\begin{array}{l}\text { 5. Knowledge of advanced } \\
\text { achievements in the field of the } \\
\text { organization and the legal basis for its } \\
\text { implementation }\end{array}$ & 3 & 8 & 6 & 5,7 \\
\hline $\begin{array}{l}\text { 6. Experience in introducing } \\
\text { innovations and overcoming } \\
\text { resistance to them }\end{array}$ & 9 & 11 & 6 & 8,7 \\
\hline $\begin{array}{l}\text { 7. Ability to attract investment for the } \\
\text { implementation of the project }\end{array}$ & 3 & 10 & 4 & 5,7 \\
\hline $\begin{array}{l}\text { 8. Understanding the risks of } \\
\text { innovation, especially radical }\end{array}$ & 11 & 11 & 10 & 10,7 \\
\hline $\begin{array}{l}\text { Sum of ratings on innovative } \\
\text { (business) characteristics }\end{array}$ & 26 & 40 & 26 & 30,7 \\
\hline
\end{tabular}

According to the data obtained, the small business manager appreciates business innovative characteristics much more than socio-psychological motivational competencies. While innovators consider personal characteristics of a leader more important for influencing the innovative development of an organization.

The minimum ratings for all categories of respondents received such a characteristic as "Innovative style of behavior", and the maximum-"desire to lead the organization to success." Unambiguously and high enough, all categories of respondents' rate "Understanding the risks of innovation, especially radical."

Comparing the assessments of innovators working in large innovation organizations and the head of a small trading enterprise, we note that the greatest deviation occurs according to the characteristic "Need to be a leader on the basis of innovation", since the creator and small business manager do not consider it necessary to prove their leadership, but introduces innovations according to business need.

To determine the priority of the leader's competencies to ensure the growth of innovative activity of the organization, we proposed the following statements for evaluation.

If the head of the organization does not have the following competencies, the introduction of digital innovation is at risk:

1. Psychological readiness for change and constant selfdevelopment. (Explanation: the leader must be ready to change himself, constantly seek and master new technologies of personal work, including digital).

2. The desire to lead the organization to success. (Explanation: first of all, the leader must be motivated to apply innovations himself, be at the head of the "innovation 
transformation" in order to achieve the company's competitiveness).

3. The need to be a leader based on innovation. (Explanation: a leader must understand that a modern leader cannot win and develop his leadership if he or she does not actively introduce innovations).

4. An innovative style of behavior. (Explanation: leaders must be the initiators of innovations and be able to create an appropriate organizational climate so that all the employees use innovative thinking to solve problems and develop new products).

5. Knowledge of advanced achievements in the industry of the organization and the legal basis for its implementation. (Explanation: for the introduction of innovations, the leader must be well aware of new technologies in the field of his or her activity, as well as how legitimate is their implementation in the organization).

6. Experience in introducing innovations and overcoming resistance to them. (Explanation: for the successful implementation of new digital technologies, it is important to have experience in implementing innovative projects, to see on the basis of this, what problems may arise in the process of implementing innovations, and how to overcome them).

7. Ability to attract investment for the project implementation. (Explanation: it is impossible to implement innovations without investments, therefore, the manager must have experience in "finding an effective investor").

8. Understanding the risks of innovation, especially radical. (Explanation: it is impossible to successfully implement innovations if manager is not prepared for minimizing the risks that can ruin any idea).

To determine the factors of the importance of innovative and motivational competence of enterprise managers and their relationship with innovative activity, we conducted a study of more than 200 respondents from 24 business structures of the Stavropol Territory (18) and other regions of the Russian Federation (6).

As a result of the study, it was found that in enterprises whose managers have a high level of innovative competence, as a rule, innovative activity takes a priority place in the management strategy. The estimates given by the leaders of the responding organizations are grouped in table 2. For comparison, the last column shows the priorities obtained by pairwise comparisons (marked with $*$ )

Table 2. Priority components of innovative and motivational competence of organizational leaders (developed by the authors on the basis of the study)

\begin{tabular}{|l|l|l|l|l|l|}
\hline \multirow{2}{*}{ Characteristic } & \multicolumn{3}{|c|}{ Averagegrade point } & \multicolumn{2}{c|}{ Priority } \\
\cline { 2 - 6 } & IE* & OO** & $\begin{array}{l}\text { In the } \\
\text { whole } \\
\text { selection }\end{array}$ & $\begin{array}{l}\text { Approval } \\
\text { Assessment } \\
\text { Method }\end{array}$ & $\begin{array}{l}\text { Pairwise } \\
\text { Compari } \\
\text { son } \\
\text { Method* }\end{array}$ \\
\hline $\begin{array}{l}\text { 1. Psychological } \\
\text { readiness for change } \\
\text { and constant self- } \\
\text { development }\end{array}$ & 10,0 & 10,2 & 10,1 & 2 & 2 \\
\hline $\begin{array}{l}\text { 2. The desire to lead } \\
\text { the organization to } \\
\text { success }\end{array}$ & 11,1 & 9,5 & 10,3 & 1 & 1 \\
\hline $\begin{array}{l}\text { 3. The need to be a } \\
\text { leader based on }\end{array}$ & 8,6 & 8,0 & 8,3 & $7-8$ & 8 \\
\hline
\end{tabular}

\begin{tabular}{|l|l|l|l|l|l|}
\hline innovation & & & & & \\
\hline $\begin{array}{l}4 . \\
\text { Aninnovativestyleof } \\
\text { behavior }\end{array}$ & 9,0 & 9,0 & 9,0 & $4-5$ & 6 \\
\hline $\begin{array}{l}\text { 5. Knowledge of } \\
\text { advanced } \\
\text { achievements in the } \\
\text { industry of the } \\
\text { organization and the } \\
\text { legal basis for its } \\
\text { implementation }\end{array}$ & 8,2 & 9,8 & 9,0 & $4-5$ & 3 \\
\hline $\begin{array}{l}\text { 6. Experience in } \\
\text { introducing } \\
\text { innovations and } \\
\text { overcoming resistance }\end{array}$ & 8,2 & 8,4 & 8,3 & $7-8$ & $4-5$ \\
\hline $\begin{array}{l}\text { 7. Ability to attract } \\
\text { investment for the } \\
\text { projectimplementation }\end{array}$ & 7,5 & 9,5 & 8,5 & 6 & 7 \\
\hline $\begin{array}{l}\text { 8. Understanding the } \\
\text { risks of innovation, } \\
\text { especially radical }\end{array}$ & 9,4 & 10,0 & 9,7 & 3 & $4-5$ \\
\hline
\end{tabular}

* innovatively active enterprises;

** other organizations;

As the analysis of personal conversations with the heads of the city's enterprises shows, the decisive motive for applying this or that innovation is the ability to adopt a well-developed brand or effective technology from competitors, if this company does not have such an opportunity, interest in other innovative projects, especially costly and risky, is lost.

In our opinion, this provision is in the framework of studying the management psychology and can be changed by creating an effective system of informational support and knowledge management for both managers and personnel of the enterprise. The complexity of the competency profile can also be represented as a polygon (Fig. 1).

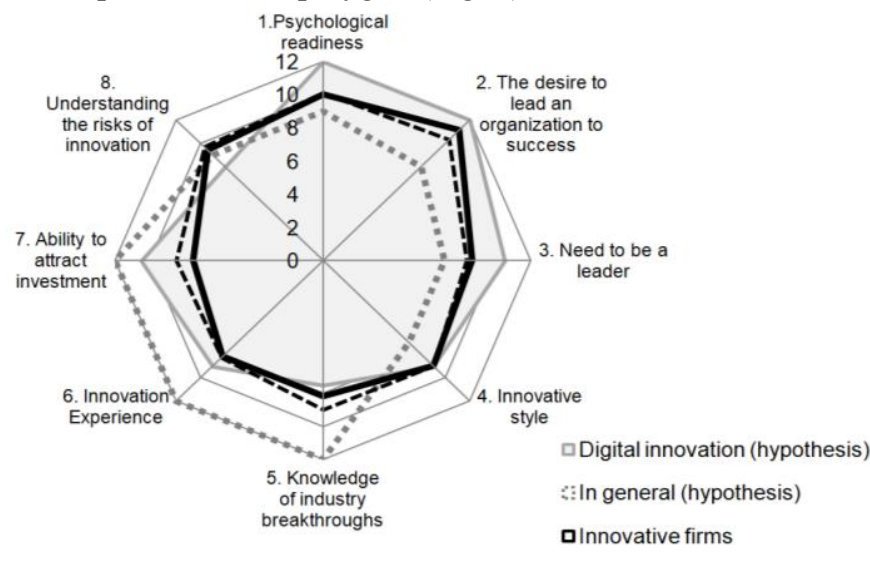

GStudied enterprises in general

Fig. 1. Competency profile of an organizational leader

As the results of the study showed, for most enterprises the leaders'motivational competence is no less significant than innovative (business) one. In this group, the most significant are "the desire to lead the organization to success" and "Psychological readiness for change and constant selfdevelopment".

It is also worth noting that all business innovative competencies received rather high marks, although a certain priority was given to "knowledge of advanced achievements in the industry of the organization" and "experience of their implementation in the organization." 
Analyzing the data obtained (Figure 3), it can be noted that our assumptions about the transformation of motivational and innovative competencies are confirmed. However, the assessments received from the respondents (black lines in Figure 1) of the competency shift towards motivational components turned out to be less significant than the expected ones (gray lines). Thus, the hypothesis was partially confirmed.

\section{CONCLUSIONS}

The development of digital information technology leads to the transformation of relations in the market system, increasing the uncertainty of the competitive environment, puts forward one of the first places the requirement for the head of the organization as the leader of change. We consider it necessary to note the need to integrate innovation into the strategic management system. In this system, innovations (as the main tool for achieving the growth of companies' competitiveness) are planned, monitored, evaluated, encouraged, that is, they are an integrated management object. In addition, managers can make better use of available (and often unused) resources for innovation. At the same time, strategic change programs are not destructive. According to researchers at McKinsey, which is confirmed in our study, the main motivators for promoting innovation are strong innovative leaders who actively lead companies to success by managing themselves, staff, innovations and other resources of the organization. The leader must change himself, showing an example of adaptation to new technologies and products. Its most important task is the formation of an innovation corporate culture. A culture of innovation suggests that leaders can skill fully overcome organizational barriers to change.

The results of the study show that in the context of digitalization, innovative leaders need to constantly improve their competencies in the direction of developing their abilities to motivate the work of highly professional creative workers who create innovations. Continuing research in the indicated direction, the authors believe it is necessary to identify the most effective tools for influencing employees who introduce innovations.

In conclusion, we note that both company executives and authorities involved in the development of innovations in the region should be interested in enhancing innovation/

\section{ACKNOWLEDGMENT}

«The reported study was funded by RFBR, project number 19310-90043»

\section{References}

[1] O. A. Boris,

A. T. Gyyazov,

I. I. Kuzmenko, T. Y. Anopchenko, "Strategic Features of Investing in Human Capital in the Era of Innovation", European Proceedings of Social and Behavioral Sciences, 59, 2019, pp. 759-766. DOI: 10.15405 / epsbs.2019.04.82

[2] P. K. Wong, Yu. P. Ho, E. Autio, "Entrepreneurship, Innovation and Economic Growth: GEM Data ". Small Business Economics, 24 (3), 2005, pp. 335-350.
[3] D. B. Audretsch, "Entrepreneurship, innovation and economic growth ", Cheltenham: Edward Elgar, 2006, $220 \mathrm{p}$.

[4] J. Barsh, M. Capozzi, J. Davidson, "Leadership and innovation ", McKinsey,2008, Quarterly,1 (36), Available: https://www.mckinsey.com/businessfunctions/strategy-and-corporate-finance/ourinsights/leadership-and-innovation)

[5] R. M. Ustaev, V. N. Parakhina, E. Patrick, E. N. Novikova, "Human Capital In Digital Economy: Modern Trends And Innovative Development Opportunities ", European Proceedings of Social and Behavioral Sciences, 86, 2019, pp.793-802. DOI: 10.15405 / epsbs.2019.04.86

[6] I. A. Esaulova, N. V. Linkova, A. A. Merkusheva, "Innovative competencies as the basis of innovative behavior of employees of the organization", Vestnik Universiteta, (5), 2015, pp.330-335.

[7] A.Vlok, "Leadership Profile for Innovation Leaders in a Research and Innovation Organization in South Africa", Procedia-Social and Behavioral Sciences, 41, 2012, pp.209-226. DOI: 10.1016 / j.sbspro.2012.04.025

[8] M. R. Buckley, M. G. Harvey, M. M. Novicevic, J. R. Halbesleben, "Leadership, organisations and the environment: applying population ecology models to understand a leader's influence on organisational performance ", International Journal of strategic Change Management, 1(1-2), 2006, pp.61-72. DOI: $10.1504 /$ IJSCM.2006.011102

[9] Yu. P. Morozov, "Innovation Management", Moscow: UNITY-DANA, 2000, 446 p.

[10] O. S. Sovetova, "Fundamentals of the Social Psychology of Innovation ", St. Petersburg: Publishing House of St. Petersburg State University, 2010, 152 p.

[11]M. S. Gençer, Y. Samur, "Leadership styles and technology: Leadership competency level of educational leaders", Procedia-Social and Behavioral Sciences, 229, 2016, pp. 226-233. DOI: 10.1016 / j.sbspro.2016.07.132

[12] C.H. Matthews, R. Brueggeman, "Innovation and Entrepreneurship: Competency Framework", Routledge, 2015, $559 \mathrm{p}$.

[13] J. P. Deschamps, "Innovation leaders: How senior executives stimulate, steer and sustain innovation ", John Wiley \& Sons, 2009, 408 p.

[14]L. Scaringella, "Knowledge, knowledge dynamics, and innovation". European Journal of Innovation Management, 19 (3), 2016, pp. 337-361. https: $/ /$ ssrn.com/abstract $=2898804$

[15]D. Horth, "Innovation Leadership. How to use innovation to lead effectively, work collaboratively, and drive results", Center for Creative Leadership, 2014, $20 \mathrm{p}$.

[16]E. I. Alekhina, V. N. Parakhina, "The relevance of stimulating innovative competence management personnel in the post-crisis conditions of the functioning of domestic enterprises", Bulletin of the North Caucasus Federal University, 2(65), 2018, pp. 55-63. 


\section{Creative Commons Attribution License 4.0} (Attribution 4.0 International, CC BY 4.0)

This article is published under the terms of the Creative Commons Attribution License 4.0

https://creativecommons.org/licenses/by/4.0/deed.en_US 